\title{
LITERASI DIGITAL DALAM MENINGKATKAN KEMAMPUAN WIRAUSAHA ONLINE PADA IBU-IBU KKPA (KOMITE KESEJAHTERAAN DAN PERLINDUNGAN ANAK) DUSUN JODOG DESA GILANGHARJO PANDAK KABUPATEN BANTUL
}

\author{
Fadjarini Sulistyowati ${ }^{*}$, Fransiska K. Agustina ${ }^{2}$ \\ 1,2 Prodi Ilmu Komunikasi STPMD “APMD” Jl. Timoho 317 Yogyakarta \\ Email: 1dzarbela@yahoo.co.id; 2siskatina69@gmail.com \\ *Penulis korepondensi
}

\begin{abstract}
Abstrak: Pengguna internet di Indonesia mengalami peningkatan tiap tahunnya. Di sisi yang lain peningkatan pengguna internet tidak diikuti dengan peningkatan kemampuan masyarakat dalam memilih informasi dan memanfaatkannya. Untuk itu, kegiatan literasi digital perlu dilakukan terutama bagi masyarakat pedesaan. Pendampingan literasi digital dalam meningkatkan kemampuan wirausaha online bagi ibu-ibu KKPA penting dilakukan karena para ibu di pedesaan perlu untuk meningkatkan kemampuannya dalam usaha produktif. Wirausaha online memiliki banyak manfaat bagi mereka karena kegiatan ini tidak memerlukan modal besar dan dapat dilakukan dari rumah. Metode pendampingan dilakukan dengan dua tahap, tahap pertama melakukan sosialisasi Pada tahap pertama dilakukan dengan sosialisasi dan diskusi tentang minat para ibu dalam melakukan wirausaha serta penyampaian pengetahuan berbisnis melalui media online. Tahap kedua pada tahap kedua mengenalkan berbagai metode wirausha online serta teknik promosi melalui media digital. Hasil dari kegiatan ini, para ibu mendapatkan pengetahuan dan ketrampilan untuk memanfaatkan media digital dalam berwirausaha.
\end{abstract}

Kata kunci: Pendampingan, literasi, digital, wirausaha, online.

\begin{abstract}
Internet users in Indonesia has been on the rise over the years. Unfortunately, this increase has not been accompanied with the increase of society's knowledge in selecting and utilizing information. Therefore, digital literacy is deemed necessary especially for village inhabitants. Digital literacy in order to boost KKPA's entrepreneurship is important to increase productive activities. Online entrepreneurship has a lot of benefits especially because it doesn't need a lot of venture capital. This mentoring is done with two steps, first step is socialization. In the first step there are socialization and discussion about the housewives' interests in doing entrepreneurship. Knowledge-sharing about businesses via online media is also being done. In the second step, there is introduction to various methods of online entrepreneurship and promotion. The results of this activity is that housewives acquire knowledge and creativity to utilize digital media for entrepreneurship.
\end{abstract}

Keywords: Mentoring, literacy, digital, entrepreneurship, online.

\section{PENDAHULUAN}

Kemajuan teknologi komunikasi telah membawa banyak perubahan dalam kehidupan manusia. Kemajuan teknologi yang pesat di bidang komunikasi telah melahirkan banyak inovasi dan gagasan baru, ide yang bertujuan untuk memudahkan proses komunikasi, manusia menjadi lebih efektif. Komunikasi melalui media sosial mempermudah proses komunikasi. (Prasanti: 2017). Di sisi yang lain, perkembangan pengguna media sosial/ internet ini belum diimbangi dengan kecermatan masyarakat dalam memfilter informasi yang mereka terima, (Intanny: 2017). Masyarakat belum semuanya memiliki kemampuan untuk memilah informasi yang benar dan bermanfaat bagi dirinya terutama di era infodemik seperti saat ini.

Salah satu yang diperlukan masyarakat adalah literasi media digital yakni kemampuan untuk mengakses dan memproses informasi dari berbagai 
bentuk transmisi, yang menurutnya kemampuan ini bukanlah kemampuan terpisah satu sama lain melainkan kemampuan dimensional dan kontinum. (Rahmadi \& Hayati, 2020). Literasi digital adalah sebuah konsep yang mengarah pada mediasi antara teknologi dan khalayak atau user untuk mempraktikkan teknologi digital secara produktif, (Kurnia \& Astuti, 2017). Literasi digital menurut UNESCO adalah kemampuan menggunakan teknologi informasi dan komunikasi (TIK) untuk menemukan, mengevaluasi, memanfaatkan, membuat dan mengkomunikasikan konten atau informasi dengan kecakapan kognitif, etika, sosial emosional dan aspek teknis atau teknologi,(Restianty, 2018).

Perkembangan media digital memberikan peluang untuk meningkatnya wirausaha online yakni lahirnya lapangan kerja baru melalui media digital. Kewirausahaan yang didukung akses internet sangat penting sebab dapat memicu kemandirian ekonomi rakyat, (Nasrullah, 2017). Perkembangan media digital dan akses pengguna yang semakin meningkat diharapkan dapat memunculkan ekonomi kreatif dan usaha-usaha baru untuk menciptakan lapangan kerja. Hal ini sejalan dengan target pemerintah untuk meningkatkan kewirausahaan, menurut data Kementrian Perindustrian, rasio wirausaha di Indonesia masih berkisar 3,1 dari populasi penduduk dan menurut data tersebut Indonesia masih membutuhkan 4 juta wirausaha baru, (Fika Nurul Ulya, 2019).

Teknologi dapat membantu manusia untuk memudahkan pekerjaan. Bila melihat data penggunaan internet tersebut maka perlu menangkap peluang wirausaha di media digital karena perilaku masyarakat Indonesia dalam memanfaatkan media online dalam jual beli sangat tinggi. Bagi ibu-ibu rumah tangga keberadaan teknologi akan dapat dimanfaatkan untuk peluang usaha. Bagi ibu-ibu media digital dapat mendorong mereka melakukan wirausaha dari rumah. Kemampuan perempuan mendapatkan penghasilan akan mendorong peningkatan kesejahteraan ekonomi keluarga. Di era saat ini, ketrampilan dasar dalam melek informasi yang tidak lain adalah kemampuan mengakses, mengevaluasi dan menggunakan informasi dari berbagai sumber secara efektif menjadi sebuah keahlian yang teramat penting dan harus dikuasai oleh semua pihak terutama perempuan Indonesia, (Priyowidodo \& Sari, 2018)

Pada masa pandemi Covid-19, pemanfaatan media digital semakin meningkat terutama untuk pembelajaran dan pembelanjaan online. Itulah sebabnya literasi media digital terutama bagi ibuibu perlu dilakukan dan kegiatan ini harus dilaksankan seperti halnya kampanye, (Setyowati, 2021). Dalam kegiatan bisnis menggunakan internet/media digital yang mulai menjamur, perempuan menjadi subyek utama baik dari sisi pembeli maupun penjual karena pada dasarnya sifat perempuan yang cenderung konsumtif dalam membeli barang. Dan ini menjadi kesempatan bagi ibu-ibu untuk produktif bekerja menggunakan media online.seperti internet dan media sosial, (Nainggolan et al., 2020)

Organisasi KKPA (Komite Kesejahteraan dan Perlindungan Anak) merupakan organisasi yang beranggotakan ibu-ibu dan mereka yang memiliki kepedulian terhadap perlindungan anak dan perempuan di tingkat desa. Salah satu sub organisasi yang cukup aktif melakukan kegiatan adalah KKPA Dusun Jodog Desa Gilangharjo. Para ibu ini melihat adanya peluang untuk meningkatkan kemampuan berwirausaha pada masa pandemi Covid-19 melalui penjualan online. Beberapa usaha sudah mulai dirintis diantaranya dengan mengembangkan kebun-kebun sayur di lahan kosong pada masa Pandemi Covid-19. Lahan ini menjadi usaha ibu-ibu untuk berkebun sayuran yang dapat dimanfaatkan untuk kebutuhan sehari-hari. Usaha kebun ini ternyata mendorong mereka untuk berwirausaha dengan menjual sayur yang merupakan hasil panen dan bibit sayur serta tanaman hias. Minat wirausaha yang besar dan peningkatan produk sayur mendorong ibu-ibu untuk merintis bisnis melalui medi digital. Hal ini dapat dimanfaatkan sebagai peluang di masa pandemi Covid19. Permasalahan yang muncul, kompetensi dalam penjualan online masih terbatas. Bahkan bukan hanya masih kurangnya kompetensi dalam bisnis online tetapi mereka masih membutuhkan peningkatan pengetahuan literasi digital. Dari permasalahan tersebut maka dilakukan kegiatan pendampingan yang merupakan bagian dari kegiatan pengabdian prodi Ilmu Komunikasi STPMD'APMD" pada masa pandemi Covid-19 untuk ibu-ibu KKPA. Dengan adanya pendampingan ini diharapkan adanya peningkatan pengetahuan literasi digital bagi ibu-ibu anggota KKPA dan mereka dapat menggunakan serta memanfaatkan media digital.

\section{METODE PELAKSANAAN}

Metode pelaksanaan pendampingan literasi digital dalam meningkatkan kemampuan wirausaha online pada ibu-ibu KKPA Dusun Jodog Pandak Bantul dilakukan dengan dua tahap. Pada tahap pertama dilakukan dengan sosialisasi dan diskusi tentang minat para ibu dalam melakukan wirausaha serta penyampaian pengetahuan berbisnis melalui media online. Tahap pertama ini dilakukan pada tanggal 9 Agustus 2020, diawali dengan pengisian kuesioner untuk mengetahui tingkat pemahamn awal tentang wirausaha online. Pada tahap kedua dilaksanakan pada tanggal 30 Agustus 2020 dengan melakukan pelatihan dan pendampingan tentang berbagai metode wirausha online serta teknik promosi melalui media digital. 
Pada tahap pertama merupakan tahap persiapan dengan penyampaian sosialisasi secara umum tentang media digital dan kewirausahaan melalui media digital. Pada tahap ini para ibu diminta untuk mendiskusikan produk yang dapat dijadikan usaha online. Dari hasil kuesioner terbukti bahwa pemahaman ibu-ibu terhadap pemanfaatan media online masih terbatas. Sekitar 55\% belum tahu tentang keberadaan UU ITE, dan hanya sekitar 45\% yang sudah mencoba bertransaksi melalui belanja online.

Tahap kedua dilanjutkan pelatihan pemasaran dan promosi dengan murah melalui media digital. Pada tahap ini disampaikan juga kiat-kiat untuk tidak tertipu dalam berwirausaha secara online.

\section{HASIL DAN PEMBAHASAN}

Desa Gilangharjo berada di wilayah Kabupaten Bantul yang merupakan penggabungan dari tiga kelurahan lama yakni Kelurahan Krekah, Kelurahan Bantulan dan Kelurahan Jodoglegi. Desa ini terdiri dari 9 pedukuhan yakni: kadisoro, Jodog, daleman, Jomboran, Kauman, Kadekrowo, Ngaran, Krekah dan Banjarawaru. Perbatasan desa sebelah Utara Desa Ringinharjo, sebelah Selatan Desa Sidomulyo, sebelah Barat Desa Triharjo dan sebelah Timur Desa Sumbermulyo. Berikut peta desa seperti Gambar 1.

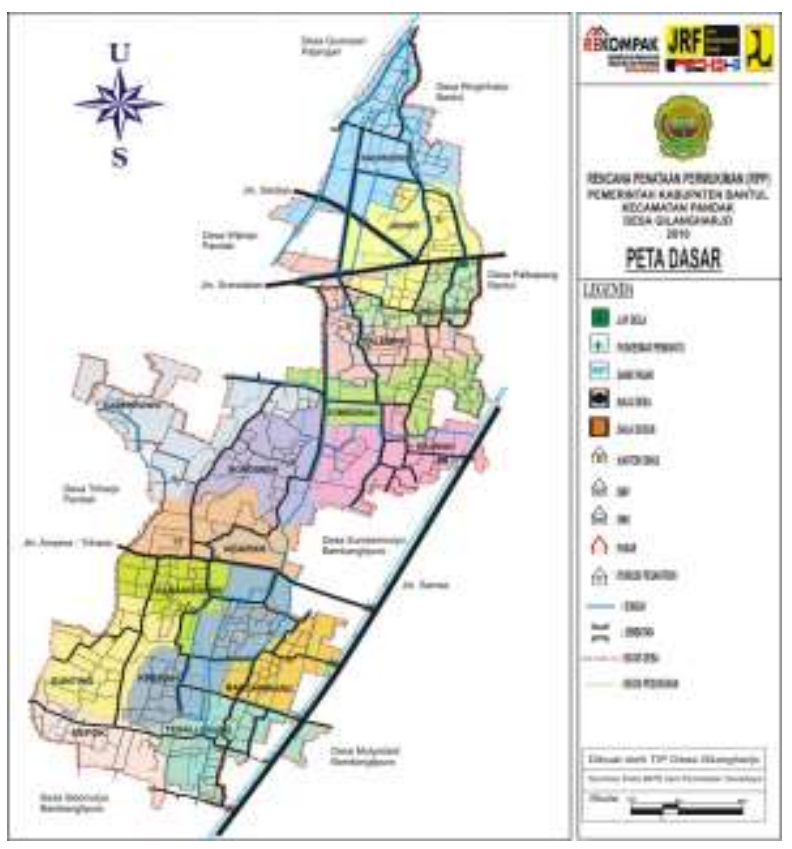

Gambar 1. Peta Desa Gilangharjo (Sumber: website Desa Gilangharjo)

Nama Desa Gilangharjo memiliki makna sebagai berikut: Gilang merupakan serapan dari nama situs budaya peninggalan zaman Mataram Islam yakni berupa petilasan yang terdapat di Janggan Kauman yakni Selo Gilang. Nama Harjo mengandung makna aman dan tentram yang didukung para pamong desa dengan segala loyalitas dan totalitas tinggi untuk mendedikasikan dirinya demi maju dan makmurnya desa. Maka nama Gilangharjo mengandung arti sebuah desa yang selalu melestarikan potensi budaya lokal dengan kerangka ekonomi kerakyatan serta ruh semangat gotong royong menuju masyarakat mandiri dan produktif melalui pemenuhan hak-hak dasar sehingga tercipta masyarakat yang sejahtera, aman dan tentram. Dusun Jodog merupakan salah satu dusun dari 15 dusun yang ada di Desa Gilangharjo. sebagian besar warga Desa Gilangharjo bermatapencaharian sebagai petani demikian juga di Dusun Jodog. Beberapa warga melakukan usaha ternak ikan lele, kerajinan batik dan usaha industri makanan ringan.

KKPA merupakan lembaga di tingkat desa yang memiliki kepedulian terhadap isu-isu pemenuhan hak-hak anak, kesetaraan gender serta upaya-upaya perlindungan terhadap anak, kekerasan dalam rumah tangga. Dalam perkembangannya KKPA ini juga bergerak dalam perlindungan perempuan di desa, khususnya terhadap kasus-kasus pernikahan dini. Dengan pendampingan dari GSM ULIN (lembaga LSM yang memiliki kepedulian terhadap kekerasan anak dan perempuan), Desa Gilangharjo membentuk KKPA yang kepengurusannnya dikuatkan dengan SK Kepala Desa. Terbentuknya KKPA Desa Gilangharjo diharapkan menjadi ujung tombak bagi penyelenggaraan perlindungan anak di desa dan mengembangkan program untuk lebih berpihak kepada anak-anak.

Ibu-ibu Dusun Jodog aktif dalam kegiatan di KKPA serta kegiatan PKK desa. Di masa Pandemi Covid-19, mereka memanfaatkan lahan kosong untuk berkebun, yang mereka beri nama Kebun sayur "Sejahtera Mandiri" Kegiatan berkebun secara rutin dilaksanakan setiap Minggu pagi. Atas kerja keras ibu-ibu ini mereka dapat menjual hasil kebun dan bibit sayuran baik Terong, Cabe, Seledri dan Tomat. Usaha ini ternyata cukup bermanfaat di masa Pandemi Covid-19 karena bisa menjadi alternatif sayur bila mereka kesulitan untuk berbelanja.

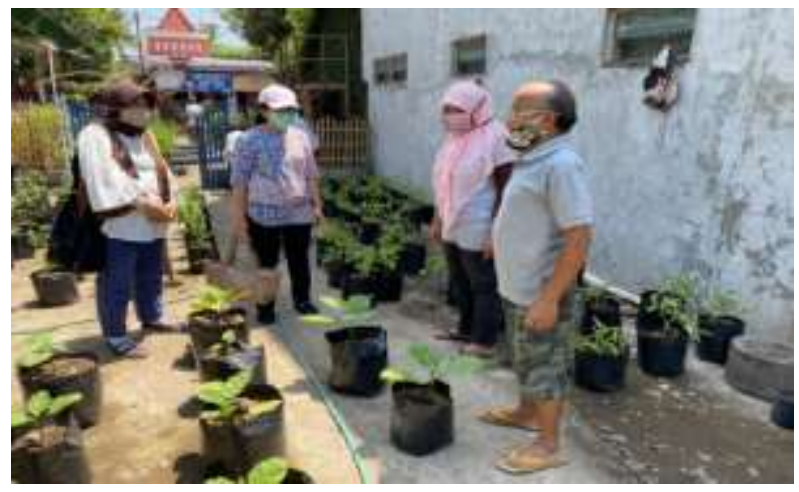

Gambar 2. Kebun sayur Dusun Jodog 
Dalam melaksanakan kegiatan pengabdian tersebut dilakukan beberapa tahap pelatihan:

1. Sosialisasi pemanfaatan media digital untuk wirausaha

Kegiatan sosialisasi diikuti ibu-ibu anggota KKPA dengan antusias. Kegiatan sosialisasi dilakukan melalui ceramah dan diskusi. Pada kegiatan ini merupakan upaya memotivasi agar mereka tergerak untuk berwirausaha online sesuai dengan situasi Pandemi Covid-19, sehingga menjadi peluang bagi ibu-ibu rumah tangga di Dusun Jodog.
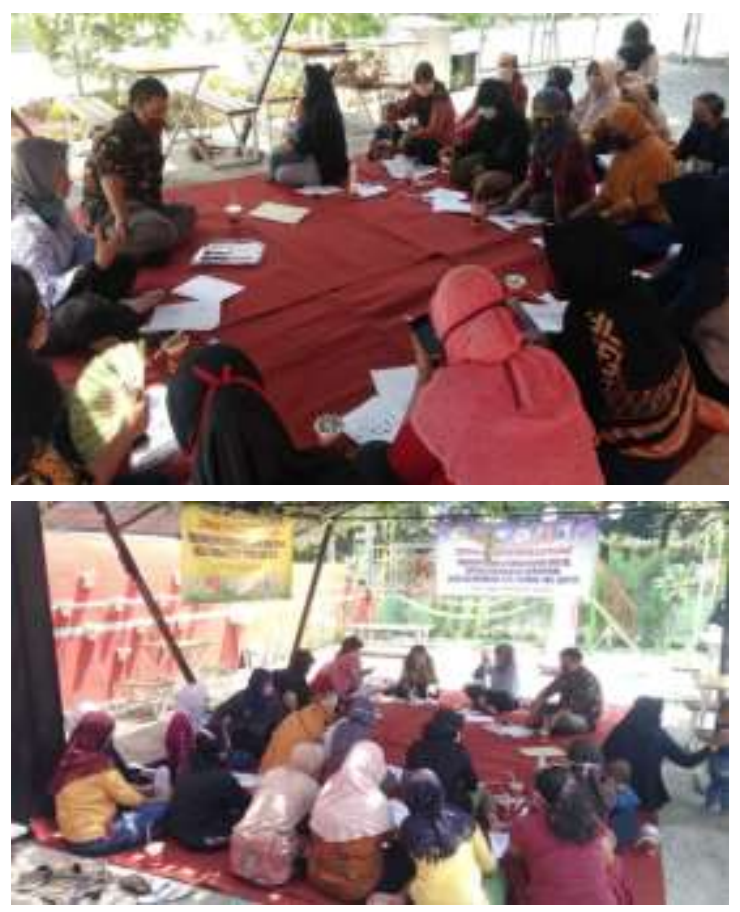

Gambar 3. Kegiatan sosialisasi

Materi sosialisasi berupa motivasi dan dorongan bagi ibu-ibu untuk memanfaatkan media digital untuk berwirausaha. Dalam sosialisasi ini disampaikan tentang potensi-potensi yang dimiliki ibu-ibu serta peluang apa saja yang bisa diraih. Peluang usaha online semakin meningkat terutama saat Pandemi Covid-19. Pada sesi ini ibu-ibu diminta menyampaikan ide peluang usaha yang dapat dijangkau mereka. Ada beberapa ibu-ibu sudah memiliki usaha kuliner yang akan ditingkatkan melalui penjualan online.

2. Pelatihan bisnis online

Kegiatan tahap kedua setelah memunculkan ide untuk berbisnis adalah upaya untuk melakukan bisnis online yang mudah dijangkau ibu-ibu. Ada tiga bisnis yang mudah dijangkau yakni: 1) Bisnis Dropship, yakni penjual bertindak sebagai perantara ke pembeli dengan membeli produk pada pihak ketiga; 2) Melalui akun sosial media, dapat dilakukan dengan membuka group whatssap, instagram, facebook dan 3) Menjadi anggota dalam toko online, saat ini sudah cukup banyak toko online: tokopedia, bukalapak, shopee dan lain-lain.

Salah satu yang menarik minat ibu-ibu adalah bisnis dengan dropship. Bisnis ini memang sederhana dan bagi masyarakat desa, mereka memiliki kemudahan untuk membeli barang melalui tangan kedua. Usaha ini tidak murni dilakukan secara online, sehingga bagi masyarakat desa lebih memudahkan bagi mereka untuk memilih produknya dan melakukan pembayaran. Bagi pembeli, mereka tidak perlu harus repot melakukan transaksi, karena proses transaksi ke supplier dibantu penjual. Keuntungan bagi penjual, ia tidak membutuhkan modal besar, karena ia hanya menjadi perantara dari pembeli ke supplier.

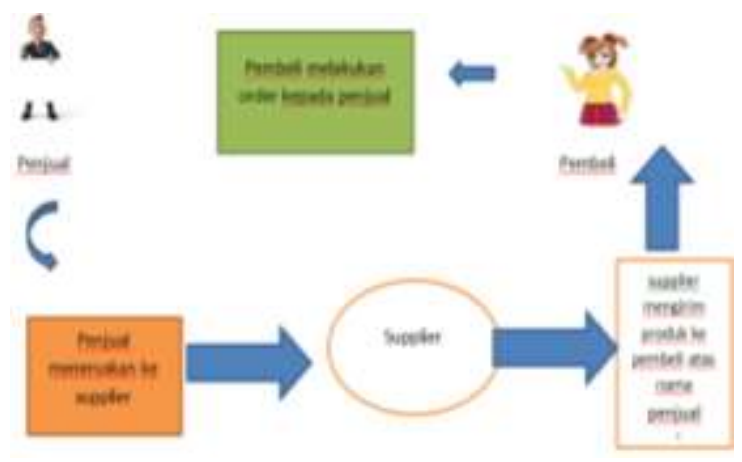

Gambar 4. Alur penjualan dengan dropshop (Sumber: pengabdi dari berbagai sumber)

Dalam tahap kedua disampaikan teknikteknik pemasaran online. Strategi pemasaran online dapat menggunakan platform yang di internet. Untuk melakukan pemasaran beberapa hal harus disiapkan:

1. Menyiapkan profil produk yang akan dipasarkan. Produk harus ditampilkan semenarik mungkin. Peranan foto dan bahasa yang komunikatif akan menmperjelas produk yang akan dijual.

2. Memanfaatkan fitur Googlemaps

- Google Maps saat ini dapat dikatakan sebagai platform peta online yang sangat populer. Semua ponsel pintar, aplikasi transportasi online dan hampir seluruh perangkat GPS menggunakan google maps sebagai platform peta online.

- Melalui fitur Google Maps, penjual dapat menampilkan informasi-informasi penting dari bisnis yang kita jalani. Beberapa informasi tersebut meliputi jenis usaha, nama tempat/usaha, titik koordinat lokasi di peta.

3. Memasarkan produk melalui instagram, facebook (FB) dan whatsapp (WA) 
Hampir sebagian besar masyarakat menggunakan smartphone. Berdasarkan survey awal dalam kegiatan pendampingan ini, para ibu-ibu KKPA 98\% memiliki smartphone dan rata-rata menngunakannya lebih dari 3 jam perhari. Sebagian ibu-ibu paham dengan penggunaan instagram, FB dan WA. Whatsapp merupakan aplikasi yang paling popular bagi ibu-ibu sehingga media ini dapat dimanfaatkan untuk pemasaran online.

4. Melalui e-commerce untuk pemasaran online Bukalapak, Lazada, Tokopedia, Blibli, Olx, Shopee, elevania, dan JD.id. Setiap platform menawarkan kelebihan dan ciri khasnya masing-masing. Beberapa platform menawarkan bebas biaya ongkos kirim, potongan harga, vouchcer belanja, ataupun jaminan keaslian produk. E-commerce ini memberikan rasa aman bagi wirausaha online karena penjual hanya menunggu pembeli.

Kegiatan pelatihan dan pendampingan ini berlangsung lancar dan para ibu KKPA sangat antusias. Pendampingan ini diakhiri dialog tentang hambatan yang dialami para ibu dalam melakukan wirasusaha online. Dari hasil kuesioner yang dibagikan kepada para ibu, ada perubahan kognitif terhadap wirausaha online. Perubahan ini dapat dilihat dari diagram (pada Gambar 5 dan 6).

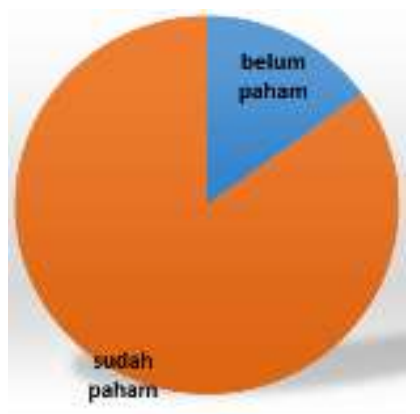

Gambar 5. Tingkat pemahaman pembelanjaan di media online sebelum pelatihan (Sumber: olahan data 2020)

Ada perubahan tingkat pemahaman setelah dilakukan pelatihan

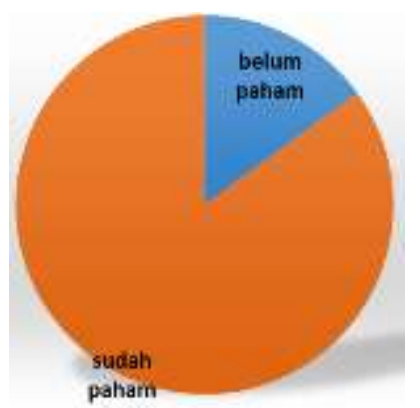

Gambar 6. Tingkat pemahaman pembelanjaan di media online setelah pelatihan (Sumber: olahan data 2020)
Selain itu, para ibu meminta materi kiat-kiat untuk menghindari penipuan dalam melakukan transaksi online. Mereka merasa khawatir bila melakukan wirausaha online akan terjadi pembeli yang melakukan penipuan.
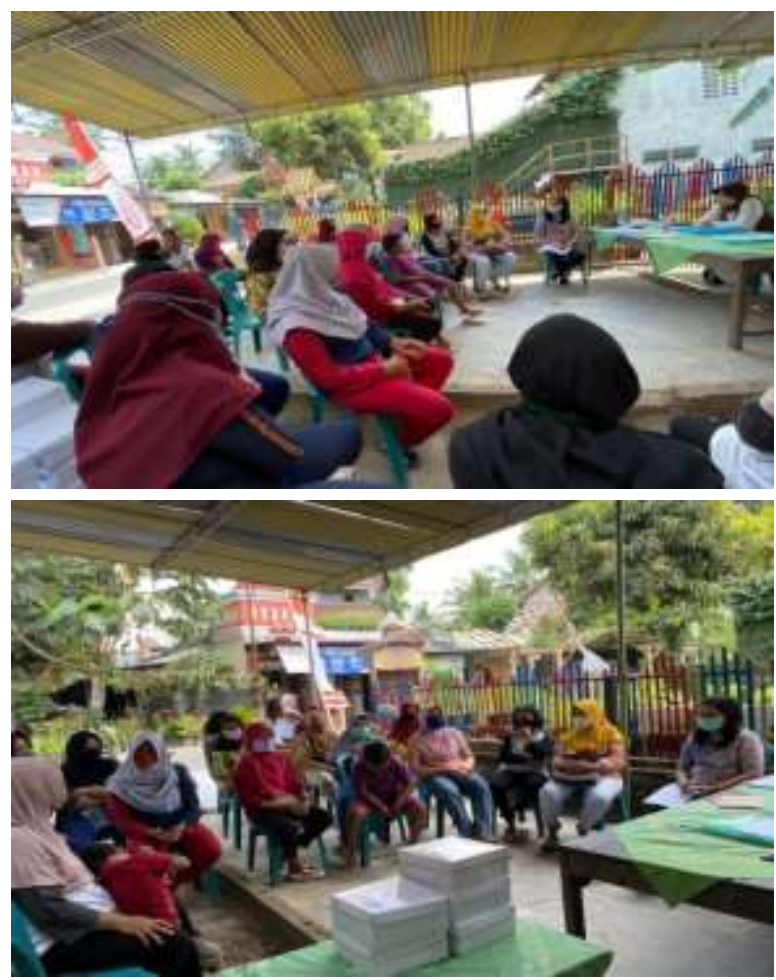

Gambar 7. Kegiatan pendampingan

\section{SIMPULAN}

Kegiatan pendampingan literasi digital bagi ibu-ibu anggota KKPA mampu meningkatkan pengetahuan dan ketrampilan dalam wirausaha online. Dari kegiatan tersebut, para ibu mulai tertarik untuk melakukan wirausaha online. Halhal yang menarik minat mereka adalah melakukan bisnis melalui dropship dan menggunakan fitur instagram atau WA di smartphone. Selain itu, mereka tertarik untuk lebih aktif memasarkan produk melalui berbagai aplikasi. Dari kegiatan ini dapat disimpulkan literasi digital memiliki manfaat bagi ibu-ibu di pedesaan dan mendorong mereka untuk menggunakan media digital untuk berwirausaha.

\section{UCAPAN TERIMA KASIH}

Kegiatan pengabdian ini merupakan bagian dari kegiatan pengabdian Prodi Ilmu Komunikasi STPMD "APMD" Yogyakarta dengan pendanaan dari internal STPMD "APMD". Terimakasih kasih kami sampaikan:

1. KKPA (Komite Kesejahteraan dan Perlindungan Anak) Dusun Jodog Desa Gilangharjo 
Kabupaten Bantul Daerah Istimewa Yogyakarta

2. STPMD "APMD" untuk pendanaan kegiatan pengabdian.

\section{DAFTAR PUSTAKA}

Fika Nurul Ulya. (2019). Indonesia masih butuh 4 juta entrepreneur baru. Kompas.Com. https://money.kompas.com/read/2019/09/05/13 3622826/indonesia-masih-butuh-4-jutaentrepreneur-baru

Intanny, V. A. (2017). E Commerce sebagai Pendorong Literasi Digital bagi UMKM di DIY.

Kurnia, N., \& Astuti, S. I. (2017). Peta Gerakan Literasi Digital Di Indonesia: Studi tentang Pelaku, Ragam Kegiatan, Kelompok Sasaran dan Mitra. INFORMASI Kajian Ilmu Komunikasi, 47(2), 18.

Nainggolan, R., Silitonga, H. T. H., \& Rambung, E. (2020). Penggunaan Media Online Untuk Bisnis Online Pemula Pada Penderita HIV. SHARE "SHaring - Action - REflection," 6(1), 23-27. https://doi.org/10.9744/share.6.1.23-27

Nasrullah, R. dkk. (2017). Materi Pendukung Sains Gerakan Literasi Nasional. Kementrian Pendidikan dan Kebudayaan, Jakarta.
Prasanti, D. (2017). Etika komunikasi dalam media sosial bagi ibu-ibu PKK di Desa Mekar Mukti Kab. Bandung Barat. 10(1), 21-34.

Priyowidodo, G., \& Sari, Y. D. (2018). Pemberdayaan Perempuan Melalui Program Edutainment Untuk Re-Aksesbilitas Informasi Berbasis Teknomedia Pada Organisasi Perempuan Gereja di GKJW Jambangan Surabaya dan Waru Sidoarjo. SHARE" SHaring-ActionREflection", 4(2), 62-70. https://doi.org/10.9744/ share.4.2.62-70

Rahmadi, I. F., \& Hayati, E. (2020). Literasi Digital, Massive Open Online Courses, dan Kecakapan Belajar Abad 21 Mahasiswa Generasi Milenial. Jurnal Studi Komunikasi Dan Media, 24(1), 91. https://doi.org/10.31445/jskm.2020. 2486

Restianty, A. (2018). Literasi Digital, Sebuah Tantangan Baru Dalam Literasi Media. Jurnal Gunahumas, 1(1), 72-87. https://ejournal.upi. edu/index.php/gunahumas/article/view/28380

Setyowati, Y. (2021). Literasi Media Digital untuk Pendampingan Anak bagi Ibu-Ibu Dusun Jodog Desa Gilangharjo Kecamatan Pandak Kabupaten Bantul. Journal of Community Development \& Empowerment, 1(2), 59-69. https://doi.org/10.29303/jcommdev.v1i2.8 